\title{
The Mediating Effect of Technical Efficiency on the Relationship between Revenue Diversification and Financial Performance of Commercial Banks in Kenya
}

\author{
Paul Teimet, \\ Lishenga Josephat, \\ Iraya Mwangi, \\ Elly Duncan,
}

Department of Finance and Accounting, School of Business, University of Nairobi, Kenya

Doi:10.19044/esj.2020.v16n19p385 URL:http://dx.doi.org/10.19044/esj.2020.v16n19p385

\begin{abstract}
Banks generate revenue through the intermediation process and perceive revenue diversification as a possible solution to financial performance challenges. The banks' income statements attest to this argument with banking activities moving gradually from interest-bearing activities to non-interest-bearing activities. The objectives of this paper were to assess the relationship between revenue diversification and return on assets and establish the mediation effect of technical efficiency on the relationship between revenue diversification and return on assets. The research used unbalanced panel data sourced from forty-two commercial banks spanning 2009 to 2018 . The study measured revenue diversification using the Hirschman-Herfindahl index while technical efficiency level was measured using data envelopment analysis. The performance attribute, return on assets was measured as a ratio of earnings before interest and tax over the total assets. The paper assessed the relationships using the panel least square regression guided by the mediation assessment process proposed by Baron and Kenny. The cross-section randomeffects model results revealed a significant positive relationship between revenue diversification and return on assets. Further, results indicated the absence of technical efficiency mediation effect on the relationship between revenue diversification and return on assets. The study recommends policy and regulatory programs that allows banks to diversify in revenue-generating activities as well as initiatives that synchronize technical efficiency in the intermediation process to improve financial performance of commercial banks, especially in emerging economies.
\end{abstract}


Keywords: Technical Efficiency, Revenue Diversification, Return on Assets, Performance

\section{Introduction}

World over, the banking business entails the intermediation of funds between lenders and borrowers in the financial system (Ally, 2013). Thus, an efficient intermediation process facilitates an effective allocation of resources to different sectors of the economy (Chiorazzo, Milani \& Salvini, 2008). Commercial banks engage in the collection of cheap deposits and other funds and use banking expertise to create loans and other investments (De Young \& Torna, 2013). In other words, a bank engages in the output-input optimization process while generating maximum possible interest and non-interest revenues. The two revenue components are crucial to the profitability aspects that determine the bank's returns, which are used to satisfy stakeholders (Stiroh, 2010). However, the banking business globally faces interruptions with which experts have associated with the frequency of regulatory changes as well as financial crisis. More than often, the occurrences subvert the generation of interest revenue portion and in effect reduce the interest margin/spread. This amplifies the weakening of other economic indicators and ultimately depletes the bank's capital base as well as limiting the funded activities (Olowokure, Tanko \& Nyor, 2015).

The intermediation efficiency guides whether a bank achieves the maximum possible output from a given minimum viable set of inputs (Koopmans, 1951). The current study focuses on technical efficiency, and given the ongoing banking digital revolution, products innovations and cost rationalization measures, a bank ostensibly offers intermediation services efficiently. That is, inputs such as customer deposits, core capital and labour are important and used to generate outputs such as loans and other investments. Thus, the transformation process would be effective given the ease of performing banking activities (Leaven \& Levine 2006). Nevertheless, commercial banks manoeuvre profit interruption tussles through the sale of bundled services and products to include non-intermediation banking activities such as propriety trading, foreign exchange trading and bancassurance for fees and commission (Teimet, Okaka and Aywa, 2011). The banking practitioners perceive this earning stream as a less regulated one, with a lower impact just in case of financial crisis inertia. Thus, the diversification strategy allows banks to venture into other business lines that generate multiple revenues from different streams. Equivocally, to maximize interest margin, a bank must earn higher interest rates on loans and other investments while paying for a lower interest rate on deposits and additional funds (Brighi \& Venturelli, 2015). 
Performance remains a fulcrum for commercial banks and a key business concern for every leader, customer or owner. This study focuses on financial performance, which largely depends on the bank's strategic objectives along with the relative efficiency level in the transformation of assets as demarcated by the resource-based theory (Terziovski \& Samson, 2000). The capacity to generate sustainable returns over time is the bank's first line of defence as it absorbs unexpected losses, strengthens capital base and improves future performance through re-investments of the retained earnings. In contrast, a loss-making bank depletes its capital base, which in turn weakens financial ratios and further puts the equity and debt holders at risk (Almazari, 2014). Therefore, banks perceive revenue diversification as a possible solution to financial performance trepidations because a given adversarial financial shock would not similarly affect multiple revenue streams, so long as they do not relate positively to each other. Experts opine that revenue diversification strategy lowers the overall risk and strengthens performance as banks sell products/services as a bundle (Lepetit, Rous \& Tarazi, 2008). That is, banks combine both interest and non-interest-bearing products as a bundle. This strategy has been possible because banks use information gained during the loan appraisal process to assess customers' risk profiles and revitalize the provision of non-interest products (Sanya \& Wolfe, 2011). Therefore, revenue diversification has an effect of lowering cyclical variation in profits, thereby, used to hedge against insolvency, liquidity problems and inefficiencies as well as creating competitive pressure among banks in a broader range of markets.

Furthermore, the resource-based theory suggests that a bank with excess resources capacity in terms of assets, market resources, skills, technology, etc., can be motivated to venture into several related business lines (Wernerfelt, 1984). The expansion of banking activities generate revenue used to cushion any adverse bearing on returns and as such, reduces the impact of financial inertia as propagated by diversification theory. Resources based approach anchors the study in the assessment of the relationship between revenue diversification, technical efficiency and returns on assets. The theory emphasizes on the availability of unemployed resource as a driver that motivates a firm to venture into more profitable market segments (Arafat, Warokka, Buchdadi, \& Suherman, 2013). Using diversification as a strategy to smoothen returns, a given financial shockwave differently affects the multiple revenue lines. Therefore, the firms' returns over time would stabilize and thus, justify improvement in financial performance (Ahuja \& Novelli, 2017). If these were the preference of banks, then diversification logically would relate positively with returns on assets. However, with additional intermediation lines, the banking business expands without restrictions. In an ordinary sense, this is expected to weaken the efficiency level in the industry (Mahmudi, et al., 2014). Primarily, a bank exists because of transactional 
inefficiency. As such, inefficiency is an inherent feature in the banking business and brings along with a certain degree of inefficiency concerning the perfect competition outcomes (Khan, Hassan, Maroney \& Francisco, 2016). Therefore, this study evaluated whether the resource-based theory holds with the inclusion of technical efficiency as a mediator in the prediction model. It is of academic curiosity to understand how technical proficiency in the intermediation process affects the relationship between revenue diversification and financial performance of commercial banks.

The empirical findings on the relationships between revenue diversification and financial performance have been inconsistent. That is, scholars have associated the inconsistency with the research context and the period in which most of the studies were undertaken. Unlike in the context of the developed market, the developing markets have weak financial systems, intermediation inefficiencies, divergence in accounting treatment and low adaptation to technological and innovations. These potentially raises generalization concerns as to whether extrapolating the findings to the context of the developing market can be valid contextually. Diversification in revenue appears to be a related type of diversification, with a general perception that interest income relates positively to non-interest income. If this is the case, it means that in the event of a given economic shock, the effect on both revenue streams would be affected similarly (Baele, Jonghe \& Vennet, 2007).

In Kenya, the banking consolidation - mergers and acquisitions - as in any other emerging economy has heightened. For example, in the last five years (2013-18), fifteen banking consolidation successfully occurred (CBK, 2018). Nevertheless, this would alter the banks' operational domain, technical efficiency and revenue diversification levels. The banks' income statements seem to attest to this argument with activities moving gradually from interestbearing activities to non-interest-bearing activities. For example, interest income scaled up by 111 percent (2009 -2018) while non-interest income increased by 115 percent in the same period. The sector generally registered improved financial strengths as evidenced by increased total net assets between 2016 and 2018. Nevertheless, the sector recorded a decline in profits by 9.6 percent, attributable to the suppressed interest income margin associated with the implementation of the interest-ceiling gap (CBK, 2018). From the foregoing, a dilemma persists as to whether revenue diversification improves banks' financial performance in the presence of a third variable. To ascertain this relationship, this study introduced technical efficiency as a third (mediating) variable. This perhaps may enhance the understanding of the concepts, which to this end, has been hard to find an investigation that provides a clear understanding. Technical efficiency in revenue generation function is a remarkably interlinking concept in the intermediation and assets transformation process. 


\section{Research Objective}

The objective of the study was to assess the effect of technical efficiency on the relationships between revenue diversification and financial performance of commercial banks in Kenya. Specific to;

a) Assess the main relationship between revenue diversification on return on assets,

b) Assess the effect of technical efficiency on the relationship between revenue diversification and return on assets.

\section{Literature Review}

In the past, several studies have examined different aspects of diversification, efficiency and performance relationships with inconsistent findings. The findings of studies which had a focus on developed economies contrasted each other despite using data from the same period. In such a case, a concern on the generality of such conclusions becomes bothersome. For instance, in the European zone (EU), Chiorazzo, Milani and Salvini (2008) used data from Italian banks to analyze diversification and profitability. The study found that revenue diversification increased risk-adjusted returns, which was consistent with other EU studies, which found positive findings (Sanya \& Wolfe, 2011; Gambacorta et al., 2014; and Brighi \& Venturelli, 2015). However, the finding contradicted other EU studies which found negative findings (Goddard et al., 2008; Afsharian et al. 2015; and Khan et al., 2016). In the USA, some studies found negative linkages between revenue diversification and financial performance (De Young \& Rice, 2004; Stiroh, 2010; and Khan, et al., 2016) contrasting others US studies which reported positive findings (De Young \& Torna, 2013).

In assessing diversification and efficiency, Khan, Hassan, Maroney and Francisco (2016) utilized a panel data from 1,940 publically listed banks world over, from 2002 to 2010 . The study found a negative relationship between revenue diversification and technical efficiency attributable to the lagged data effect. Arafat, Warokka, Buchdadi and Suherman (2013) evaluated returns and diversification relationship using data from Indonesian banks, covering 2005 to 2007 . The study found that revenue diversification had a statistically significant and positive relationship with both returns on assets and equity, which was in line with the empirical findings of Leaven and Levine (2006).

In analyzing the impact of efficiency on performance in the Europeanbanking sector, Afsharian, Kryvko and Reichling (2015) used a data set from 27 countries between 2005 and 2009. The authors found that technical efficiency related more to a volatile asset with lower market value. The study focused on developed markets, where capital market systems seemingly advanced with a multi-regulated financial system. Gyan, Brahman and 
Rayenda (2017) investigated the moderation effects of efficiency on a diversification-performance relationship using panel data from 319 firms. The study found a positive relationship, however, not as a moderating variable, but as an intervening variable. Nguyen (2018) assessed the influence of diversification on the efficiency of six ASEAN countries using the stochastic frontier approach from 2007 to 2014. The study contended that diversified banks enjoyed higher profit efficiency and that more asset-diversified banks enjoyed only higher persistent profit efficiency. In evaluating Indian banks' performance and efficiency relation, Kaur and Kaur (2013) used a DEA technique on the panel data from 1990 to 2008. The authors found that the most influential inefficiency was allocative relative to technical inefficiency.

From the foregoing, it is clear that there is no consensus in the literature findings and seemingly, the discord in the strand of literature can be associated with data segmentation, endogeneity, sampling technique and geographical location. All these may foster a possible disparity in the findings. From the foregoing, a dilemma persists as to whether revenue diversification improves banks' returns in the presence of technical efficiency. To ascertain this relationship, the present study introduced technical efficiency as a mediating variable, perhaps to enhance the understanding of the concepts and unravel the theoretical puzzle.

\section{Conceptual Framework}

The current study premised technical efficiency as a third (mediator) variable, which transmits the effect of the independent variables onto the dependent variable (MacKinnon, Lockwood, Hoffman, West \& Sheets, 2002). The conceptual model guiding the study is as presented in Figure 1.

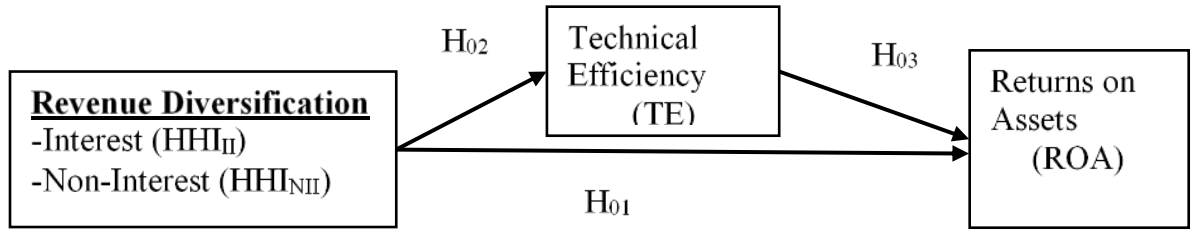

Figure 1: Conceptual Model

In the model, the arrows show the direction of the hypothesized relationship. The figure indicates that revenue diversification can relate directly to the return on assets as shown by the arrow $\mathrm{H}_{01}$. Either the relationship can be intervened by the technical efficiency as demonstrated by the path represented by $\mathrm{H}_{02}$ and $\mathrm{H}_{03}$. The Baron and Kenny (1986) s' mediation model suggested four conditions; firstly, the independent variable must relate significantly with the dependent variable in the absence of the third variable $\left(\mathrm{H}_{01}\right)$. Secondly, the independent variable must relate significantly with the 
third (mediating) variable in the absence of dependent variable $\left(\mathrm{H}_{02}\right)$. Thirdly, the third (mediator) variable must relate significantly with the dependent variable in the absence of the independent variable $\left(\mathrm{H}_{03}\right)$. Finally, the independent and the dependent relationship becomes insignificantly in the presence of the third (mediator) variable. A full mediation occurs when the relationship becomes insignificant and partial if significant with material change.

\section{Data and Methodology}

The study used secondary panel data extracted from the central bank of Kenya (CBK) database stretching from 2009 to 2018 and across 42 commercial banks. This generated 420 data points. The panel data was appropriate since the study utilized a wide range of statistical panel tests available for analysis, and certainly does not limit the use of specific statistics. More so, a panel data analysis achieves better regression results because it allows for control of unobserved heterogeneity and recognizes cross-sectional as well as time-series dimensions. This ultimately reduces the bias of the estimators as suggested by Kothari (2010).

\section{Return on Assets}

The paper considered the return on assets (ROA) as the dependent variable, a proxy for financial performance. ROA is the most used and appropriate measure which satisfies almost all stakeholders of funds such as shareholders, debtors, creditors, debenture, bondholders, etc. The study measured ROA using earnings before interest and tax (EBIT) over total assets (TA). The ratio shows how best a bank uses its investment funds in generating returns (Almazari, 2014). The model was as shown in equation 1.

$$
\mathrm{ROA}=\frac{E B I T}{T A} \text { percentage. }
$$

Where : ROA is the return on assets,

: EBIT is earnings before interest and tax,

: TA is the total assets.

\section{Revenue Diversification}

The study conceptualized revenue diversification as the independent variable and measured using the Herfindahl (1950) and Hirschman (1945) index. The index is a sum-up of weighted squared exposures as a percentage of total exposure. The model was as shown in equation 2.

$$
\mathrm{HHI}=\sum_{i=1}^{n}\left(\frac{x i}{Q}\right)^{2}
$$

Where $: Q=\sum_{i=1}^{n} x i+\cdots .+x n$ representing the total revenue exposure, 
$: \sum=$ Sum

$: \mathrm{HHI}=$ Revenue diversification index,

$: X i=$ an exposure variable.

Typically, the index is adjusted from a unit (1-HHI) such that the index increases with the level of diversification. This allows easing interpretation which ranges from zero to one $(0<\mathrm{HHI}<1)$. Where zero is the undiversified (focused) bank, while one is a fully diversified bank. Various authors have closely used the model to measure diversification in the banking industry (Staikouras et al., 2006; Stiroh, 2004; and Chiorazzo et al., 2008).

\section{Technical Efficiency}

The study conceptualized technical efficiency (TE) as the third (mediating) variable and measured using the deterministic data envelopment analysis (DEA), a non-parametric model developed by Charnes, Cooper and Rhodes (1978). DEA measures the technical efficiency of a firm with multiple inputs that generate various outputs (Coelli, Rao, O'Donnell \& Battese, 2005). The study used DEA to compute for the technical efficiency index based on inputs - deposits, core capital and labour and outputs-loans \& investments. The composite index shows the rate at which a bank converts multiple inputs into various outputs optimally. The optimal weighted general equation was as shown in equation 3.

$$
\operatorname{Max}_{u y}\left(u^{\prime} y_{i t} / v x_{i t}\right)
$$

St. $\quad u^{\prime} y_{j t} / v^{\prime} x_{j t} \leq 1 \quad(j=1,2 \ldots n),(i=1,2 \ldots . . n)(t=1,2 \ldots . T)$

$u, v \geq 0$

Where $: u=$ vector output (loans $\&$ investments) weights $\mathrm{M}^{*} 1$ matrix of inputs $x_{i t}$

$: V=$ vector input (deposits, capital $\&$ labour) weights $\mathrm{K}^{*} 1$, matrix of outputs, $\mathrm{y}_{i t}$.

$: X_{i t}=$ vector input used by bank $i$ at time $t$,

$: Y_{i t}=$ vector output offered by bank $i$ at time $t$.

The process entails solving for $u$ and $v$ so that the efficiency measure for bank $i$ is maximized subject to the constraint, such that all efficiency measures must be less or equal to one ( $\mathrm{TE} \leq 1)$. However, a problem of multiple solutions occasioned by optimality $\left(u^{*}, v^{*}\right)$ and non-optimality $(u, v)$ scores occurs. The study avoided the problem by imposing a constraint, $v^{\prime} x_{i}=$ 1 as shown in equation 4 .

$\operatorname{Max}_{\mu y}\left(\mu y_{i}\right)$

St. $\quad V^{\prime} x j=1$

$\mu y_{i}-v^{\prime} x_{j} \leq 0, \quad(j=1,2 \ldots . . n)$ 
However, this study considered variable return to scale (VRS). The convexity constraint $N I$ ' $\lambda=1$ was introduced to derive the equivalent envelopment form of the output-oriented model as shown in equation 5.

$\operatorname{Min} \theta \lambda \theta$,

St. $\quad$ NI' $\lambda=1$

$-Y_{i}+Y \lambda \geq 0$

$\theta x_{i}-X \lambda \geq 0, \lambda \geq 0, \theta \leq 1$

Where : $1 \leq \theta<\infty$,

$: \theta=$ vector scalar,

$: \lambda=N x l$ vector of constants.

Equation 5 forms a convex-hull of intersecting planes, which envelops the data points more tightly. This provided the technical efficiency (TE) score, where $\theta-1$ is the proportional increase in outputs achieved by the $\boldsymbol{i}^{\text {th }}$ decisionmaking unit with input quantity held constant. $1 / \theta$ defines a TE score ranging from zero to one $(0 \leq \mathrm{TE} \leq 1)$.

\section{Model Specification}

Hausman (1978) test assessed model suitability with the null hypothesis that the random-effects model (REM) was appropriate against the alternative of the fixed-effects model (FEM) appropriateness. The results were as shown in Table 1 .

Table 1: Correlated Random Effects-Hausman Tests

\begin{tabular}{|c|c|c|c|c|}
\hline \multicolumn{5}{|c|}{ Test cross-section random effects } \\
\hline Test Summary & & Chi-Sq. Statistic & Chi-Sq. d.f. & Prob. \\
\hline Cross-section random & & 2.676739 & 3 & 0.4442 \\
\hline \multicolumn{5}{|c|}{ Cross-section random effects test comparisons: } \\
\hline Variable & Fixed & Random & Var(Diff.) & Prob. \\
\hline $\begin{array}{l}\text { Interest Diversification }\left(\mathrm{HHI}_{\mathrm{II}}\right) \\
\end{array}$ & 5.683414 & 5.177673 & 0.262717 & 0.3238 \\
\hline Non-interest Diversification ( $\left.\mathrm{HHI}_{\mathrm{NII}}\right)$ & 4.087362 & 4.075320 & 0.085832 & 0.9672 \\
\hline Technical Efficiency (TE) & 1.184227 & 1.340290 & 0.020118 & 0.2712 \\
\hline
\end{tabular}

Table1, shows the test summary for cross-section random with statistical insignificance, that is, the chi-square test statistics $\left(\chi^{2}=2.7, \mathrm{df}=3\right.$, $\mathrm{P}=.44)$. Thus, the study failed to reject the null hypothesis $\left(\mathrm{H}_{0}\right)$ of the REM appropriateness. The rejection implies the study adopted REM for analysis henceforth.

\section{Data Stationarity}

The study used panel-based unit root tests to explore stationarity and cointegration order $1(d)$ between interest diversification, non-interest 
diversification, technical efficiency and return on assets. The null hypothesis for Levin, Lin \& Chu assumes common unit root process while ADF fisher assumes individual unit root process. The results were as shown in Table 2.

Table 2: Panel Unit Root Test

\begin{tabular}{cllllrr}
\hline \hline \multicolumn{2}{l}{ Variable Levin, Lin \& Chu t* } & Prob. & ADF- Fisher Chi-square & Prob. & Cross-section Obs \\
\hline \hline ROA & -11.3049 & 0.0000 & 152.368 & 0.0000 & 42 & 356 \\
HHI $_{\text {II }}$ & -13.3016 & 0.0000 & 175.517 & 0.0000 & 42 & 359 \\
HHI $_{\mathrm{NII}}$ & -16.1475 & 0.0000 & 226.449 & 0.0000 & 42 & 361 \\
$\mathrm{TE}$ & -10.8525 & 0.0000162 .774 & & 0.0000 & 42 & 351 \\
\hline \hline
\end{tabular}

Probabilities for Fisher tests are computed using an asymptotic Chi-square distribution. All other tests assume asymptotic normality.

Source: Research Data 2020

Table 2 results indicate statistical significance for all cases and across the forty-two firms. In other words, LLC for common unit root process and ADF results for individual unit root process were statically significant ( $\mathrm{P}$ $<.05)$. Therefore, based on the results of the panel data the, study concluded that the variables co-integrated well at order $1(0)$ and thus, safe to adopt other panel data models that assume data stationarity.

\section{Auto-Correlation}

The study assessed serial correlation presence using the BreuschGodfrey Lagrange Multiplier (LM) test, with the null hypothesis of serial correlation. The results were as shown in Table 3.

Table 3: Breusch-Godfrey LM Test

\begin{tabular}{cccc}
\hline \hline F-statistic & 112.6918 & Prob. F(2,413) & 0.17662 \\
Obs*R-squared & 147.5745 & Prob. Chi-Square(2) & 0.07945 \\
\hline \hline
\end{tabular}

Table 3 shows insignificant $\mathrm{LM}$ test results $(\mathrm{F}(2,413)=112.7, \mathrm{P}=$ .17 ; and $\left.\chi^{2}=147.6, \mathrm{P}=.079\right)$. The results imply that there was no first-order linear autocorrelation and variables were independent of each other as such, safe to adopt other statistics for forecasting.

\section{Heteroscedasticity}

The study assessed heteroscedasticity using the Breusch and Pagan test, with the null hypothesis of error terms homoscedasticity. The results were as shown in Table 4.

Table 4: Breusch-Pagan-Godfrey Test Results

\begin{tabular}{llll}
\hline \hline F-statistic & 0.410320 & Prob. F $(3,414)$ & 0.5457 \\
Obs*R-squared & 1.239167 & Prob. Chi-Square(3) & 0.6436 \\
\hline \hline
\end{tabular}

Table 4 reveals insignificant results $\left(\mathrm{F}(3,414)=.41, \mathrm{P}=.54, \chi^{2}=1.24\right.$, $\mathrm{P}=.64)$, which imply that error terms were homogeneous. 


\section{Data Stability}

The study assessed data stability using cumulative sum (CUSUM) test of the recursive residuals with the $5 \%$ critical lines as shown in figure 1 .

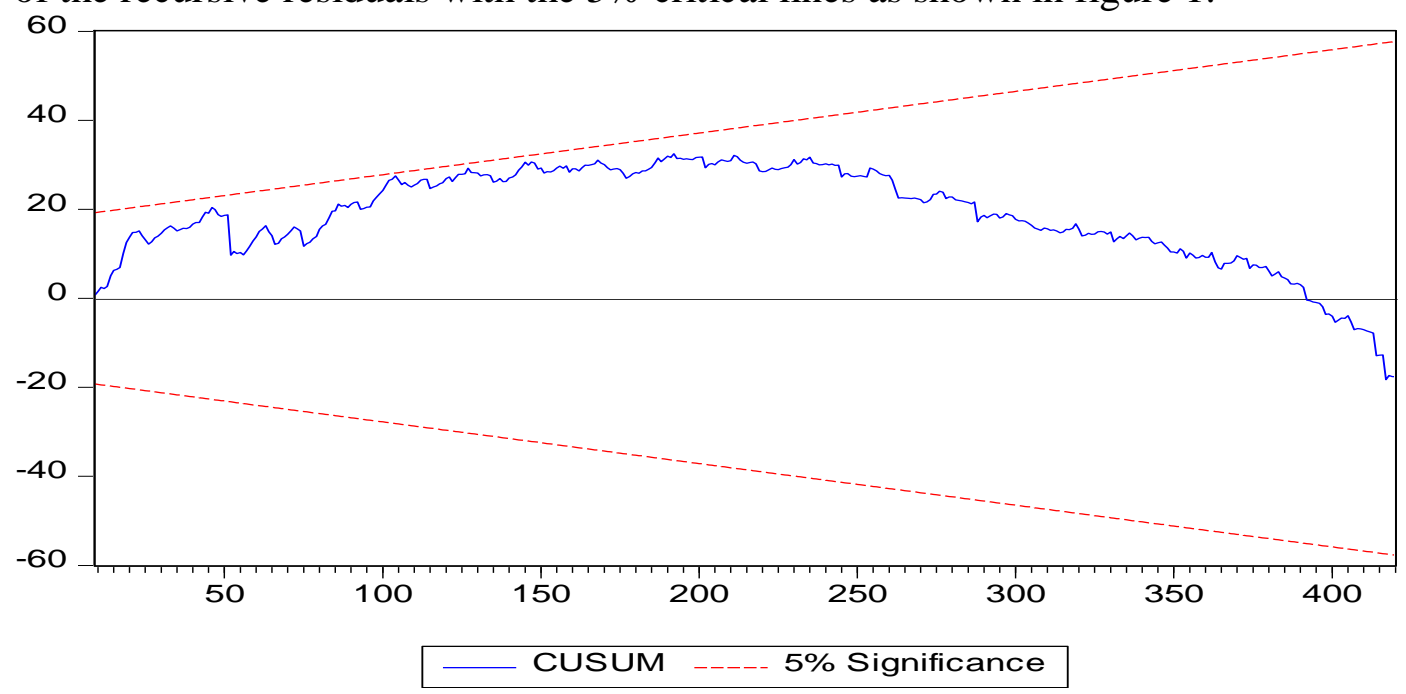

Figure 2: Cumulative Sum Test of Recursive Residuals Source: Research Data, 2020

The figure shows that the cumulative sum of squares was generally within the significance of red lines, suggesting that the residual variances were stable. This implies that panel data was stable for a successful forecast.

\section{Descriptive Statistics}

To enhance the understanding of the conceptualized variables, the study generated descriptive statistics as shown in Table 5.

Table 5: Descriptive Statistics Results

\begin{tabular}{ccccc}
\hline \hline Statistic/ Variable & ROA & HHI II $_{\text {HHI }}$ & HE \\
\hline Mean & 2.030310 & 0.356114 & 0.626782 & 0.696953 \\
Median & 2.495000 & 0.358499 & 0.656750 & 0.726165 \\
Maximum & 10.40000 & 0.646323 & 0.772946 & 1.000000 \\
Minimum & -32.15000 & 0.009151 & 0.060852 & 0.000000 \\
Std. Dev. & 3.760565 & 0.123577 & 0.118239 & 0.230446 \\
Skewness & -3.234673 & -0.153518 & -2.136800 & -0.574359 \\
Kurtosis & 23.22292 & 2.548873 & 8.744152 & 2.805642 \\
Jarque-Bera & 7889.328 & 5.211257 & 897.0316 & 23.75324 \\
Probability & 0.000000 & 0.073857 & 0.000000 & 0.000007 \\
\hline \hline
\end{tabular}

Source: Research Data 2020

Table 5 shows that ROA, $\mathrm{HHI}_{\mathrm{II}}, \mathrm{HHI}_{\mathrm{NII}}$ and TE had mean scores of $2 \pm 3.8, .36 \pm .1, .63 \pm .2$ and $.69 \pm .2$, respectively. The results provide a preview that on average commercial banks assets earned a return of about 2 percent $(\bar{x}$ 
$=2.03)$ during the period. Further banks were 36 percent $(\bar{x}=.356)$ diversified in interest income and 63 percent $(\bar{x}=.627)$ in non-interest income with intermediation technical efficiency level of 70 percent $(\bar{x}=.696)$ during the study period. Further, all data variables had negative skew implying the majority of observations felt to the left of the mean, whilst Kurtosis were positive implying a heavy-tailed distribution than the normal distribution. Apart from $\mathrm{HHI}_{\mathrm{II}}$, the Jarque-Bera significance reveals non-normal panel data distribution. Tabachnick and Fidell (2011), assets that non-normality is relatively common for large samples, however, the study ignored the assumption in consideration of the large sample size.

\section{Correlation Analysis}

The study employed a correlation analysis to understand the relationship between variables. The results were as presented in Table 6 .

Table 6: Correlation Matrix

\begin{tabular}{|c|c|c|c|c|c|}
\hline & & HHIII & HHI $_{\text {NII }}$ & TE & ROA \\
\hline $\mathrm{HHI}_{\mathrm{II}}$ & $\begin{array}{l}\text { Pearson Correlation } \\
\text { Sig. (2-tailed) }\end{array}$ & 1 & & & \\
\hline $\mathrm{HHI}_{\mathrm{NII}}$ & $\begin{array}{l}\text { Pearson Correlation } \\
\text { Sig. (2-tailed) }\end{array}$ & $\begin{array}{l}.141^{* *} \\
.004\end{array}$ & 1 & & \\
\hline $\mathrm{TE}$ & $\begin{array}{l}\text { Pearson Correlation } \\
\text { Sig. (2-tailed) }\end{array}$ & $\begin{array}{l}-.010 \\
.839\end{array}$ & $\begin{array}{l}.165^{* *} \\
.001\end{array}$ & 1 & \\
\hline ROA & $\begin{array}{l}\text { Pearson Correlation } \\
\text { Sig. (2-tailed) }\end{array}$ & $\begin{array}{l}.118^{*} \\
.015\end{array}$ & $\begin{array}{l}.164^{* *} \\
.001\end{array}$ & $\begin{array}{l}.148^{* *} \\
.002\end{array}$ & 1 \\
\hline
\end{tabular}

Table 6 shows that all variables related positively with each other with statistical significance, except for $\mathrm{TE}$ and $\mathrm{HHI}_{\mathrm{II}}$ which exhibited a negative and insignificant relation $(\mathrm{r}=-.01, \mathrm{P}=.839)$. Interestingly all variables related positively with return on assets, implying that with an increase in interest diversification, non-interest diversification and technical efficiency, the predicted returns on assets increases proportionately.

\section{Hypothesis Testing and Discussions}

The study assessed the relationships between revenue diversification, technical efficiency and financial performance of commercial banks in Kenya. The assessment process entailed the adoption of the four steps proposed by Baron and Kenny. That is, first, the independent variable must relate significantly with the dependent variable in the absence of the third (mediator) variable. Secondly, the independent variable must relate significantly with the third (mediator) variable in the absence of the dependent variable. Thirdly, the third (mediator) variable must relate significantly with the dependent variable 
in the absence of an independent variable. Fourthly, the independent variable must relate insignificantly with the dependent variable in the presence of the third (mediator) variable for a mediation effect to have occurred.

In the first step, the study performed a panel data regression to assess the relationship between revenue diversification and return on assets in the absence of technical efficiency as shown in Table 7.

Table 7: Regression Results for Revenue Diversification on Return on Assets

Dependent Variable: Return on Assets (ROA)

Method: Panel EGLS (Cross-section random effects)

Sample: 20092018

Periods included: 10

Cross-sections included: 42

Total panel (unbalanced) observations: 420

Swamy and Arora estimator of component variances

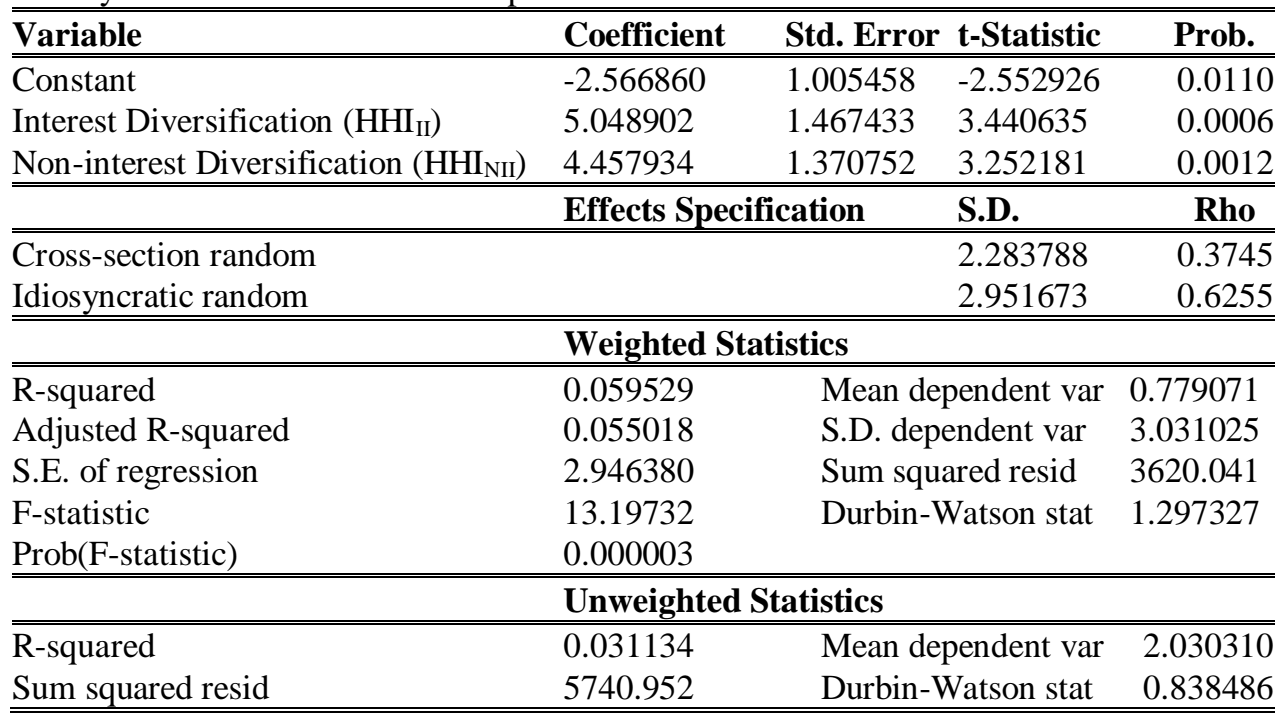

Source: Research Finding 2020

Table 7 revealed a positive linear and statistically significant relationship between return on assets and both interest diversification $\left(\beta_{1}=\right.$ 5.05, $\mathrm{t}=3.44, \mathrm{P}=.00)$ and non-interest diversification $\left(\beta_{2}=4.46, \mathrm{t}=3.25, \mathrm{P}\right.$ $=.00)$. The effects specification revealed that the cross section and idiosyncratic standard deviation were 2.28 and 2.95 respectively, with the corresponding association of 38 percent $(\mathrm{Rho}=.3745)$ and 63 percent $(\mathrm{Rho}=$ $.6255)$. Further, the weighted statistics were significant $\left(\mathrm{R}^{2}=.059, \mathrm{~F}=13.197\right.$, $\mathrm{P}=.000, d=1.29$ ). Based on the first assessment results, the study found a significant positive relationship between revenue diversification and financial performance, with a prediction model shown in equation 6 .

$$
\begin{aligned}
& \mathrm{ROA}_{\mathrm{it}}=\beta_{0}+\beta_{1}\left(\mathrm{HHI}_{\mathrm{II}}\right)_{\text {it }}+\beta_{2}\left(\mathrm{HHI}_{\mathrm{NII}}\right)_{\text {it }}+\mu_{\mathrm{it}}+\varepsilon_{\text {it }} \\
& \mathrm{ROA}=-2.56+5.05\left(\mathrm{HHI}_{\mathrm{II}}\right)+4.46\left(\mathrm{HHI}_{\mathrm{NII}}\right)
\end{aligned}
$$


Where : ROA is the predicted return on assets, representing the dependent variable,

: -2.56 is the predicted value of $\mathrm{ROA}$ when $\mathrm{HHI}_{\mathrm{II}}$ and $\mathrm{HHI}_{\mathrm{NII}}$ values are zero, : 5.05 is the estimate change of $\mathrm{HHI}_{\mathrm{II}}$ on $\mathrm{ROA}$ when $\mathrm{HHI}_{\mathrm{NII}}$ value is zero, : 4.46 is the estimate change of $\mathrm{HHI}_{\mathrm{NII}}$ on $\mathrm{ROA}$ when $\mathrm{HHI}_{\mathrm{II}}$ value is zero,

Equation 6 means that for a unit increase in both $\mathrm{HHI}_{\mathrm{II}}$ and $\mathrm{HHI}_{\mathrm{NII}}$, the predicted ROA increases by 5.05 and 4.46 units respectively, all else unchanged. Thus, the first assessment condition was to the satisfactory, meaning that the study progressed to the second step of mediation assessment.

In the second step, the study performed a panel regression to assess the relationship between revenue diversification and technical efficiency in the absence of return on assets as shown in Table 8.

Table 8: Regression Results for Revenue Diversification and Technical Efficiency

Dependent Variable: Technical Efficiency (TE)

Method: Panel EGLS (Cross-section random effects)

Sample: 20092018

Periods included: 10

Cross-sections included: 42

Total panel (unbalanced) observations: 420

Swamy and Arora estimator of component variances

\begin{tabular}{|c|c|c|c|c|}
\hline Variable & Coefficient & Std. Error & t-Statistic & Prob. \\
\hline Constant & 0.536482 & 0.066664 & 8.047588 & 0.0000 \\
\hline Interest diversification $\left(\mathrm{HHI}_{\mathrm{II}}\right)$ & -0.088136 & 0.097812 & -0.901073 & 0.3681 \\
\hline \multirow[t]{2}{*}{ Non-Interest Diversification $\left(\mathrm{HHI}_{\mathrm{NII}}\right)$} & 0.303586 & 0.095669 & 3.173308 & 0.0016 \\
\hline & \multicolumn{2}{|c|}{ "Effects Specification } & S.D. & Rho \\
\hline \multirow{2}{*}{\multicolumn{3}{|c|}{$\begin{array}{l}\text { Cross-section random } \\
\text { Idiosyncratic random }\end{array}$}} & 0.080299 & 0.1235 \\
\hline & & & 0.213899 & 0.8765 \\
\hline & \multicolumn{4}{|c|}{ Weighted Statistics } \\
\hline R-squared & 0.024136 & \multicolumn{2}{|c|}{ Mean dependent var } & 0.453221 \\
\hline Adjusted R-squared & 0.019455 & \multicolumn{2}{|c|}{ S.D. dependent var } & 0.215090 \\
\hline S.E. of regression & 0.213432 & \multicolumn{2}{|c|}{ Sum squared resid } & 18.99573 \\
\hline F-statistic & 5.156749 & \multicolumn{2}{|c|}{ Durbin-Watson stat } & 1.525549 \\
\hline \multirow[t]{2}{*}{ Prob(F-statistic) } & 0.006133 & & & \\
\hline & \multicolumn{3}{|c|}{ Unweighted Statistics } & \\
\hline R-squared & 0.027572 & Mean dep & pendent var & 0.696953 \\
\hline Sum squared resid & 21.63764 & Durbin- $\mathrm{V}$ & Natson stat & 1.344248 \\
\hline
\end{tabular}

Source: Research Finding 2020

Table 8 results show that technical efficiency related negatively and statistically insignificant with interest diversification $\left(\beta_{1}=-.088, \mathrm{t}=-.90, \mathrm{P}=\right.$ .368). The insignificant test results mean that the second condition was violated. This implies that mediation assessment was not viable, thus the study dropped the variable. However, the results revealed that technical efficiency related significantly with non-interest diversification $\left(\beta_{1}=.30, \mathrm{t}=3.17, \mathrm{P}=\right.$ 
.00) with cross-section and idiosyncratic standard deviation of .08 and .21 respectively. The corresponding proportions of total variants were 2 percent $($ Rho $=.1235)$ and 88 percent $($ Rho $=.8765)$ respectively. The overall model was statically significant $\left(\mathrm{R}^{2}=.024, \mathrm{~F}=5.16, \mathrm{P}=.00, d=1.5\right)$. Based on the results, the second condition was to the satisfactory of the study with a prediction model shown in equation 7

$$
\begin{aligned}
& \mathrm{TE}_{\mathrm{it}}=\beta_{0}+\beta_{1}\left(\mathrm{HHI}_{\mathrm{II}}\right)_{\text {it }}+\beta_{2}\left(\mathrm{HHI}_{\mathrm{NII}}\right)_{\text {it }}+\mu_{\mathrm{it}}+\varepsilon_{\mathrm{it}} \\
& \mathrm{TE}=.54+-.09\left(\mathrm{HHI}_{\mathrm{II}}\right)+.3\left(\mathrm{HHI}_{\mathrm{NII}}\right) .
\end{aligned}
$$

Where: TE is the predicted Technical efficiency, representing mediator : .54 is the predicted value of $\mathrm{TE}$ when $\mathrm{HHI}_{\mathrm{II}}$ and $\mathrm{HHI}_{\mathrm{NII}}$ values are zero, : -.09 is the estimate change of $\mathrm{HHI}_{\mathrm{II}}$ on $\mathrm{TE}$ when $\mathrm{HHI}_{\mathrm{NII}}$ value is zero, : .3 is the estimate change of $\mathrm{HHI}_{\mathrm{NII}}$ on $\mathrm{TE}$ when $\mathrm{HHI}_{\mathrm{II}}$ value is zero,

The interpretation of equation 7 means that with a unit increase in both $\mathrm{HHI}_{\mathrm{II}}$ and $\mathrm{HHI}_{\mathrm{NII}}$, TE decreases by .09 and increases .3 units respectively, other things held constant. Thus, the second condition was satisfied and the study retained the variable in the third step of mediation assessment.

The third step entailed regression analysis to assess the relationship between technical efficiency and return on assets in the absence of non-interest diversification as shown in Table 9.

Table 9: Regression Results for Technical Efficiency and Return on Assets

Dependent Variable: Return on Assets (ROA)

Method: Panel EGLS (Cross-section random effects)

Sample: 20092018

Periods included: 10

Cross-sections included: 42

Total panel (unbalanced) observations: 420

\begin{tabular}{|c|c|c|c|c|}
\hline Variable & Coefficient & Std. Error & t-Statistic & Prob. \\
\hline Constant & 0.920991 & 0.608102 & 1.514535 & 0.1306 \\
\hline Technical Efficiency (TE & 1.575340 & 0.710824 & 2.216217 & 0.0272 \\
\hline & \multicolumn{2}{|c|}{ Effects Specification } & $\begin{array}{ll}\text { S.D. } \\
\end{array}$ & Rho \\
\hline Cross-section random & & & 2.156378 & 0.3352 \\
\hline \multirow[t]{2}{*}{ Idiosyncratic random } & & & 3.036859 & 0.6648 \\
\hline & \multicolumn{3}{|c|}{ Weighted Statistics } & \\
\hline R-squared & 0.011598 & \multicolumn{2}{|c|}{ Mean dependent var } & 0.837082 \\
\hline Adjusted R-squared & 0.009233 & \multicolumn{2}{|c|}{ S.D. dependent var } & 3.053071 \\
\hline S.E. of regression & 3.038968 & \multicolumn{2}{|c|}{ Sum squared resid } & 3860.367 \\
\hline F-statistic & 4.904800 & \multicolumn{2}{|c|}{ Durbin-Watson stat } & 1.219792 \\
\hline \multirow[t]{2}{*}{ Prob(F-statistic) } & 0.027321 & & & \\
\hline & \multicolumn{3}{|c|}{ Unweighted Statistics } & \\
\hline R-squared & 0.019169 & \multirow{2}{*}{\multicolumn{2}{|c|}{$\begin{array}{l}\text { Mean dependent var } \\
\text { Durbin-Watson stat }\end{array}$}} & 2.030310 \\
\hline Sum squared resid & 5811.853 & & & 0.829009 \\
\hline
\end{tabular}

Swamy and Arora estimator of component variances

Source: Research Finding 2020 
Table 9 shows that technical efficiency related positively and statistically significantly with return on assets $\left(\beta_{1}=.92, \beta_{1}=1.58, \mathrm{t}=2.22, \mathrm{P}\right.$ $=.027)$ and the effect specification standard deviation of cross-section and idiosyncratic errors were 2.16 and 3.04 respectively. The total variance associated with the cross-section random and idiosyncratic terms were 33 percent $(\mathrm{Rho}=.3352$ and 66 percent $(\mathrm{Rho}=.6648)$ respectively. The overall model was statically significant $\left(\mathrm{R}^{2}=.012, \mathrm{~F}=4.9, \mathrm{P}=.027, d=1.2\right)$. The results show that the relationship existed as presented by a prediction shown in equation 8 .

$$
\begin{aligned}
& \operatorname{ROA}_{i t}=\beta_{0}+\beta_{1}(\mathrm{TE})_{i t}+\mu_{\mathrm{it}}+\varepsilon_{\mathrm{it}} \\
& \mathrm{ROA}=.92+1.58(\mathrm{TE}) \ldots \ldots \ldots \ldots \ldots \ldots \ldots \ldots \ldots \ldots
\end{aligned}
$$

Where : ROA is the predicted return on assets, representing the dependent variable,

: .92 is the predicted value of ROA when TE value is zero,

: 1.58 is the estimated change of TE on ROA.

Equation (8) implies that with a unit increase in technical efficiency, the predicted return on assets increases by 1.58 units, all other things being equal. Thus, the third condition was satisfied because technical efficiency related significantly with return on assets in the absence of non-interest diversification. Since the necessary condition in the preceding three steps (13) above were satisfactory concerning non-interest diversification and returns on assets, the study progressed to the fourth.

The fourth step entailed a panel regression of non-interest diversification (independent) and returns on assets (dependent) in the presence of technical efficiency (mediator). The regression results were as shown in Table 10.

Table 10: Regression Results for Non-Interest Diversification, Technical Efficiency and Return on Assets

Dependent Variable: ROA

Method: Panel EGLS (Cross-section random effects)

Sample: 20092018

Periods included: 10

Cross-sections included: 42

Total panel (unbalanced) observations: 420

Swamy and Arora estimator of component variances

\begin{tabular}{lllll}
\hline \hline Variable & Coefficient & Std. Error & t-Statistic & Prob. \\
\hline \hline Constant & -1.843381 & 1.000143 & -1.843117 & 0.0660 \\
Non-interest Diversification $\left(\mathrm{HHI}_{\mathrm{NII}}\right)$ & 4.822486 & 1.385558 & 3.480538 & 0.0006 \\
Technical Efficiency (TE) & 1.221495 & 0.708353 & 1.724416 & 0.0854 \\
\hline \hline & Effects Specification & S.D. & Rho \\
\hline \hline Cross-section random & & 2.191571 & 0.3490 \\
Idiosyncratic random & & 2.993426 & 0.6510 \\
\hline \hline
\end{tabular}




\begin{tabular}{llll}
\hline \hline & Weighted Statistics & \\
\hline \hline R-squared & 0.039425 & Mean dependent var & 0.816116 \\
Adjusted R-squared & 0.034818 & S.D. dependent var & 3.044944 \\
S.E. of regression & 2.991448 & Sum squared resid & 3731.633 \\
F-statistic & 8.557471 & Durbin-Watson stat & 1.265912 \\
Prob(F-statistic) & 0.000228 & & \\
\hline \hline & \multicolumn{4}{l}{ Unweighted Statistics } & \\
\hline \hline R-squared & 0.039194 & Mean dependent var & 2.030310 \\
Sum squared resid & 5693.196 & Durbin-Watson stat & 0.846710 \\
\hline \hline
\end{tabular}

Source: Research Finding 2020

Table 10 reveals that in the presence of technical efficiency noninterest diversification effect on return on assets remained positive and statistically significant $\left(\beta_{1}=4.82, t=3.48, \mathrm{p}=.006\right)$ while technical efficiency effect on return on assets was insignificant $\left(\beta_{2}=1.22, \mathrm{t}=1.72, \mathrm{p}=.085\right.$. Further, the cross-section and idiosyncratic random effects standard deviation were 2.19 and 2.99 respectively. In other words, 35 percent (Rho =.349) and 65 percent $(\mathrm{Rho}=.651)$ of the total variance were associated with the crosssection and random idiosyncratic effects respectively. The model fitness summary results showed a significant prediction model for non-interest diversification and technically efficiency $\left(\mathrm{R}^{2}=.039, \mathrm{~F}=8.56, \mathrm{P}=.00\right)$. The significance of non-interest diversification statistics suggests the absence of mediation effect on the relationships between revenue diversification and financial performance. Based on these results, the study found that technical efficiency does not mediate the relationship. However, the resulting panel linear regression equation was as shown in equation (9)

$$
\begin{aligned}
& \mathrm{ROA}_{\text {it }}=\beta_{0}+\beta_{1}\left(\mathrm{HHI}_{\mathrm{NII}}\right)_{\text {it }}+\beta_{2}(\mathrm{TE})_{\text {it }}+\mu_{\mathrm{it}}+\varepsilon_{\mathrm{it}} \\
& \mathrm{ROA}=-1.8+4.8\left(\mathrm{HHI}_{\mathrm{NII}}\right)+1.2(\mathrm{TE}) \ldots \ldots \ldots \ldots \ldots \ldots
\end{aligned}
$$

Where : ROA the predicted return on assets, representing the dependent variable,

$:-1.8$ is the predicted value of ROA when $\mathrm{HHI}_{\mathrm{NII}}$ and TE are zero,

: 4.8 is the estimated change of $\mathrm{HHI}_{\mathrm{NII}}$ on ROA when TE value is zero,

$: 1.2$ is the estimated change of TE on ROA when $\mathrm{HHI}_{\mathrm{NII}}$ value is zero,

The prediction model means that for every additional unit increase in both non-interest diversification and technical efficiency, the predicted return on assets increases proportionately by 4.8 and 1.2 units respectively, ceteris paribus.

\section{Findings and Conclusion}

The objective of the study was to assess the mediating effect of technical efficiency on the relationship between revenue diversification and return on assets of commercial banks in Kenya. Specifically, the assessment 
process followed closely the Baron and Kenny four-step model. Firstly, the study estimated the direct relationship between revenue diversification and return on assets in the absence of technical efficiency. Secondly, evaluated the relationship between revenue diversification and technical efficiency in the absence of financial performance. Thirdly, assessed the relationship between financial performance and technical efficiency in the absence of revenue diversification. Fourthly, the study evaluated the effect of revenue diversification (independent) on financial performance (dependent) in the presence of technical efficiency (mediator).

The assessment and findings as guided by Baron and Kenny (1986) s' criteria showed that; return on assets exhibited a positive and statistically significant relationship with both interest diversification $\left(\beta_{1}=5.05, \mathrm{t}=3.44\right.$, $\mathrm{P}=.00)$ and non-interest diversification $\left(\beta_{2}=4.46, \mathrm{t}=3.25, \mathrm{P}=.00\right)$ in absence of the technical efficiency in the first step. Put it differently, both interest diversification and non-interest diversification affects return on assets positively. In the second step, technical efficiency related insignificantly with interest diversification $\left(\beta_{1}=-.088, \mathrm{t}=-.90, \mathrm{P}=.368\right)$ and significantly with non-interest diversification $\left(\beta_{1}=.30, \mathrm{t}=3.17, \mathrm{P}=.00\right)$ in absence of return on assets. In the third step, technical efficiency related significantly with return on assets $\left(\beta_{1}=.92, \beta_{1}=1.58, \mathrm{t}=2.22, \mathrm{P}=.027\right)$ in absence of non-interest diversification. Finally, in the fourth step, the relationship between noninterest diversification and return on assets remained statistically significant $\left(\beta_{1}=4.82, t=3.48, p=.006\right)$ in the presence of technical efficiency.

Based on the first null hypothesis $\left(\mathrm{H}_{1}\right)$ test results, the study concluded that return on assets relates positively with both interest diversification income and non-interest diversification. This implies that banks use the revenue streams complementarily to smoothen banks return on assets. Based on the second null hypothesis $\left(\mathrm{H}_{2}\right)$, the study concluded that technical efficiency does not mediate on the relationship between revenue diversification and return on assets of commercial banks in Kenya. These results provided sufficient evidence that technical efficiency related to both interest and non-interest diversification and return on assets but not as a mediator. That is, technical efficiency does not accelerate or decelerate the intermediation process as a channel through which commercial banks can embrace diversification to enhance profitability. That is, technical efficiency derails diversification benefits as banks purchase inputs (deposits, capital \& labour) and transform them into outputs (loans \& investments). The finding of the current study supports previous studies that found the existence of a positive relationship between revenue diversification, technical efficiency and financial performance (Arafat et al., 2013; Kryvko and Reichling, 2015; Gyan et al., 2017; Nguyen, 2018). However, it contrasts Khan et al., (2016) study which 
found a negative relationship between revenue diversification and financial performance.

The finding of the study attracts bank managers, regulators, depositors and investors in general. The implication is that it guides commercial bank management to appreciate the linkages between resource availability, diversity in revenue generation, efficiency in the intermediation process and complexity management function while maximizing bank's returns on assets. The fact that technical efficiency does not intervene the relationship between revenue diversification and financial performance, could be an indicator that commercial banks' functional input-out trade-off and the management thereof, do have a significant impact on the revenue rebalancing and decision-making process. The regulators, on the other hand, can develop guidelines for commercial banks to avoid unnecessary bank-runs, declines (or bursts) in financial indicators and unwarranted receivership (or management) of banks. It would be useful in designing remedial schemes or programs to support the operations of banks as well as entrepreneurs to diversify more and adopt valuable sources of income, which maintains banks' stability.

\section{References:}

1. Afsharian, M., Kryvko, A. \& Reichling, P. (2015). Efficiency and performance. Journal of operations and quantitative management, 2 (1), 241-263.

2. Ahuja, G. \& Novelli, E. (2017). Redirecting research efforts on the diversification-performance linkage. Academy management annals, 11(1), 342-390.

3. Ally, Z. (2013). Comparative analysis of the financial performance of commercial banks in Tanzania. Research journal of finance and accounting, 4 (19), 133-143.

4. Almazari, A. (2014). Impact of internal factors on bank profitability. Journal of applied finance and banking, 4(1), 125-140.

5. Arafat, M., Warokka, A., Buchdadi, A. \& Suherman, D. (2013). Banking efficiency and performance. Journal of business advancement, 6(1), 13-23.

6. Baele, L., Jonghe, O. \& Vennet, R. (2007). The stock market value and bank diversification. Journal of banking \& finance, 3(1), 1999-2023.

7. Baron, R. \& Kenny, D. (1986). The moderator-mediator variable distinction in social psychological research. Journal of social psychology, 5(1), 1173-1182.

8. Birger Wernerfelt (1984). A Resource-Based View of the Firm. Strategic management journal, 5(2), 171-180. 
9. Brighi, P. \& Venturelli, V. (2015). How functional and geographic diversification affect banks' profitability during the crisis. Finance research letters, $1-10$.

10. Central Bank of Kenya (2018). Bank supervision annual reports. Available at http://www. centralbank.go.ke.

11. Charnes, A., Cooper, W. \& Rhodes, E. (1978). Measuring the efficiency of the decision-making units. Journal of operations research 2(3), 429-444.

12. Chiorazzo, V., Milani, C. \& Salvini, F. (2008). Income diversification and performance of Italian banks. Journal of financial services, 3(3), 181-203.

13. Coelli, J., Rao, P., O’Donnell, J. \& Battese, G. (2005). An introduction to efficiency and productivity analysis $\left(2^{\text {nd }} \mathrm{Ed}\right)$. Springer Science and Business Media, Inc.

14. De Young, R. \& Rice, T. (2004). Non-interest income and financial performance of commercial banks. Financial review, 3(9), 101-127.

15. De Young, R. \& Torna, G. (2013). Non-traditional banking activities and bank failures during the financial crisis. Journal of financial intermediation, 2(2), 397-421.

16. Gambacorta, L., Scatigna, M. \& Yang, J. (2014). Diversification and bank profitability: a nonlinear approach. Applied economics letters, 21(6), 438-441.

17. Goddard, J., McKillop, D. \& Wilson, S. (2008). The diversification and financial performance of US credit unions. Journal of banking \& finance, 3(2), 1836-1849.

18. Gyan, A., Rayenda, B. \& Bakri, K. (2017). Diversification strategy, efficiency and firm performance. International business and finance, 4(3), 1103-1114.

19. Hausman, A. (1978). Specification tests in econometrics. Econometrica, 4(6), 251-271.

20. Herfindahl, O. (1950). Concentration in the steel industry. Columbia University.

21. Hirschman, A. (1945). National power and the structure of foreign trade. Berkeley and University of California Press.

22. Kaur, P., \& Kaur, G. (2013). A study of the cost efficiency of Indian commercial banks. African journal of business management, 7(15), 1238-1249.

23. Khan, A., Hassan, M., Maroney, N. \& Francisco, R. (2016). Efficiency, value addition, and performance of US banks. Corporate ownership and control, 14(1), 78-95.

24. Koopmans, T. (1951). Efficient allocation of resources. Econometrica, 19 (4), 455- 465. 
25. Kothari, C. R. (2010). Research Methodology: Methods and Technique. $2^{\text {nd }}$ Edition, New Delhi: New Age International Publishers.

26. Leaven, L. \& Levine R. (2006). Diversification discount in financial conglomerates. Journal of financial economics, 2(4), 36-53.

27. Lepetit, L., Rous, P. \& Tarazi, A. (2008). Bank income size and risk: An empirical analysis of European banks. Journal of banking and finance, 32(8), 1452-1467.

28. MacKinnon, P., Lockwood, M., Hoffman, M., West, G., \& Sheets, V. (2002). A comparison of methods to test mediation and other intervening variable effects. Psychological methods, 7(1), 83-104.

29. Mahmudi, H., Ismael, M., Ananda C. \& Khusaini, M. (2014). Analysis of technical efficiency of education organizer: a case study at junior high school in Mataram city. International journal of business and management, 3 (7), 23-32.

30. Nguyen, T. (2018). Diversification and bank efficiency in six ASEAN countries. Global finance journal, 3(7), 57-78.

31. Olowokure, O., Tanko, M. \& Nyor, T., (2015). Firm structural characteristics and financial reporting quality. International business research, 9(1), 106-122.

32. Sanya, S. \& Wolfe, S. (2011). Can banks in emerging countries benefit from revenue diversification-Journal of financial services research, 40 (2), 79-101.

33. Staikouras, C. K., \& Wood, G. E. (2006). The determinants of bank profitability. International business and economics research journal, 3(6), 57- 68.

34. Stiroh, K. (2004). Diversification and Banking: Non-interest Income is the answer - Journal of money, credit and banking, 36(5), 853-882.

35. Stiroh, K. (2010). Diversification in Banking (Eds.). The Oxford Handbook of Banking, 146-171.

36. Tabachnick, B.G., \& Fidell, L.S. (2001). Using multivariate statistics. (4th eds). New York: Harper Collins.

37. Teimet, Okaka \& Aywa (2011). Income source diversification and financial performance of commercial banks in Kenya. International journal of business and public management 1(1), 26-35.

38. Terziovski, M. \& Samson, D. (2000). The effect of firm size on organizational performance. The TQM Magazine, 12(2), 144-148. 